\title{
Evaluation of the Regulation Changes on Environment and Forestry in Indonesia
}

\author{
Helmi*, Fauzi Syam, Nopyandri, Akbar Kurnia Putra \\ Faculty of Law, Jambi University, Indonesia. \\ *Corresponding author e-mail: helmi@unja.ac.id
}

\section{ARTICLE INFO}

Keywords:

Government; Regulation;

Environment; Forestry

How to cite:

Helmi, Syam, F.,

Nopyandri, and Putra, A.K.

(2020). Evaluation of the

Regulation Changes on

Environment and Forestry

in Indonesia, Hasanuddin

Law Review, 6 (1): 100-108

DOI:

10.20956/halrev.v6i1.2290

\begin{abstract}
This article aims to examine the correlation between the concept of proper enforcement of the law as stipulated in Article 5 (2) of the 1945 Constitution of Indonesia and the establishment and implementation of government regulation on environment and forestry. This article is a normative legal research with statute, historical, and conceptual approaches. The result shows that proper legal enforcement means two things, namely, establishment and enactment of government regulation by the President and the content of the regulation that does not contradict the law. Failure to comply with the law means the President does not establish or enforce a government regulation as mandated or the content of the regulation is not in line with the law. If the President does form or enforce the implementation of government regulation, this means that the President violates his oath and promise to uphold the Constitution and to serve the nation. If the content of the regulation contradicts with the law, it can be canceled. In this situation, the government needs to realign the content of existing regulations. The ministry involved in legal drafting is called to oversee the content and follow through with revisions. All party involves in the making of law and regulation, such as the People Representatives, the President, or the Minister, is reminded to carefully formulate a government regulation.
\end{abstract}

Copyright $\odot 2020$ HALREV. All rights reserved.

\section{Introduction}

Government regulation is an executive instrument to proper enactment of laws. According to Article 7 (1) of the Act No. 12 of 2011 on the Establishment of Laws and Regulations, government regulation is an implementing regulation that provides details and specific policies of legislation. Positioning below the legislation, the drafting, content, and the procedure of implementation of government regulation shall 
not contradict the legislation. ${ }^{1}$ Based on Article 25 (1) of the Act on the Establishment Laws and Regulation of 2011, government regulation bill is set in a preparation program, must contain list of titles, and shall primarily include the legal material that is related to the enactment of laws. The bill is set for a period of one year. ${ }^{2}$ The content of bill derives from the ministry or non-ministerial institution in accordance with their filed of work, the preparation of the legal drafting must be coordinated by the ministry of law and determined with the Decree of the President. In a certain circumstance, a ministry or a non-ministerial institution may submit a bill outside the planning for drafting of government regulation based on the need of the law or the decision of the Supreme Court. Article 29 of the law explains that further provisions regarding the procedures for planning the preparation of government regulations are regulated by Presidential Regulation.

The power to establish a government regulation rests at the hand of a President who holds the highest governmental authority. Based on Article 5 (2) of the Constitution, "The President establishes a government regulation to enforce the law properly." Consequently, the presidential power to establish a government regulation is called attribution. The President is responsible to enforce the laws properly including establishing and implementing government regulation. From 1999 to 2019, Indonesia has 618 laws $^{3}$ and 1808 government regulations. ${ }^{4}$ This study focuses on the Act Number 32 of 2009 on Protection and Management of Environment and the Act Number 41 of 1999 on Forestry. A review of the four legislations found that the President has published 21 of 27 mandated government regulation as shown in table 1 below.

Table 1. Number of Mandated and Established Government Regulation

\begin{tabular}{llccc}
\hline \multicolumn{2}{c}{ Legislation } & & \multicolumn{2}{c}{ Number of Regulation } \\
\cline { 3 - 4 } & & As mandated by the laws & Established \\
\hline $\begin{array}{l}\text { The Act Number 32 of 2009 } \\
\text { Management of Environment } 5\end{array}$ & Protection & and & 8 & 6 \\
\hline \begin{tabular}{l} 
The Act Number 41 of 1999 on Forestry $^{6}$ \\
\hline
\end{tabular} & Total & 19 & 15 \\
\hline
\end{tabular}

There is a gap between the number of the mandated and established regulations. Based on the data, the President is required to produce six more regulations concerning environment and forestry. Having reviewed the content and the procedure of the

1 Helmi and Iskandar, I. (2020). The Authority of Internal Auditor to Prevent Corruption Committed by Civil Servants and Government Official. Jambe Law Journal, 2(2): 139-62.

2 Article 25 (2) of Act on Establishment of Laws and Regulations of 2011.

3 Retrieved from http://peraturan.go.id/uu.html, Kementerian Hukum dan Hak Asasi Manusia Republik Indonesia, 22 Februari 2019

4 Retrieved from http://peraturan.go.id/pp.html, Kementerian Hukum dan Hak Asasi Manusia Republik Indonesia, 22 Februari 2019.

5 The Act takes into effect in October 3rd, 2009. Based on Article 126 of the Act, implementing regulations shall be established one (1) year after the commencement of the Act. Consequently, all mandated government regulations should be available on October $4^{\text {th }}, 2010$.

6 This Act takes into effect on September 30th, 1999. As written in the Transitory Provisions of the law, "All implementing regulations of the available legislations concerning forestry, as long they do not run counter to the provision of this Act, shall remain applicable until the issuance of such regulations based on the provisions of this Act." 
establishment of the regulations, the authors found that, 1) until the allotted time, the President fails to follow through the mandate of the legislation to produce 27 government regulations; 2) one regulation contains the material that includes more than what is allowed or mandated by the law; and 3) ministerial regulation concerning environment and forestry is applied even though the government regulations are not established.

The President, as the highest authority to formulate government regulations, has the constitutional responsibility to implement the laws accordingly. Nevertheless, in reality, it seems to be normal to breach the law despite the various legal implications that will emerge due to failure to uphold the law, such as, the President can be observed as violating the Constitution and the governance and the national development program cannot be effectively performed because there is no operational legal basis to do so. For example the case of the establishment of State Administrative Court (hereinafter referred to as PTUN). Based on the Act Number 5 of 1986 on PTUN, PTUN should be established in every region in Indonesia. However, due to the absence of government regulation on the establishment of PTUN, this mandate cannot be realized. It was when the Government Regulation Number 41 of 1991 concerning PTUN assigned that PTUN can be established.

The same thing happens to the planning for the protection of environment. Since the commencement of the Act Number 41 of 1999 on Forestry and Act Number 32 of 2009 on the Protection and Management of Environment, the President has not yet to publish Customary Law. Consequently, there appears legal uncertainty for indigenous people to cultivate customary forest in Indonesia.

\section{Method}

The type of research is a normative study that examines the rules, norms, and regulations related to the problems of research.7 This article is a normatif legal research with statute, historical, and conceptual approaches. ${ }^{8}$

\section{The Meaning of Proper Enforcement of the Law and Its Relation to the Government Regulation on Environment and Forestry}

Article 5 (2) of the Constitution mandates the President to enforce the law properly. This statement means two things. First, government regulation is an implementing regulation; hence, the establishment of such regulation shall be consistent with the Law. Second, the President is obliged to formulate and enact all the mandated government regulations.

Referring to the hierarchical order of legislation, ${ }^{9}$ government regulation is below the Law. Therefore, the Law serves as the basis for the establishment of such regulation and the government regulation shall not operate in counter to the Law. The harmony between the Law and the government regulation can be seen in the content of both legislations. According to Article 6 (1) of the Act Number 12 of 2011 of the Establishment of Laws and Regulations (hereinafter referred to UU-PPP), the

\footnotetext{
Nasution, B.J. (2008). Metode Penelitian Ilmu Hukum. Bandung: Maju Mundur. p. 87

Marzuki, P.M. (2005). Penelitian Hukum, Prenadamedia Group Jakarta, Revision Edition, p. 35

Hierarchy means classification of types of laws and regulations which is based on the assumption that the lower level legislations shall not contradict with the higher level ones.
} 
foundations of the content of laws and regulations include protection; humanity; nationalism; kinship; sense of archipelago; equity; and/or balance and harmony. Laws and regulations can also include other appropriate principles as long as they are in line with the laws and regulation.

An inventory of Act on the Protection and Management of Environment of 2009 found that 6 of 8 government regulations are published. Meanwhile, based on the Act on Forestry of 1999, the President has established 16 of 19 mandated regulations. One of the established regulations is Government Regulation Number 27 of 2012 concerning Environmental Permit (Regulation on Environmental Permit of 2012). Article 1 (35) of the regulation states that environmental permit refers to a permit granted to individuals who are required to have an assessment of environmental impact (or Amdal or UKL-UPL) of their business or activities. The issuance of such permit ensures the protection and management of the environment as well as a prerequisite to obtain a business permit. Referring to the provision of Article 1 of the regulation, environmental permit is different from business permit. ${ }^{10}$ As a primary requirement for environmentrelated business, the issuance of environmental permit especially the requirements, mechanisms and timeline, the authority to publish and oversee the business should be arranged carefully.

The Act on the Protection and Management of Environment of 2009 emphasizes the importance of environmental permit to protect and manage the environment. Article 123 indicates that all sort of permits related to environmental management as issued by the Governor, or Major/Regent, within the exercise of their power, shall be integrated into an environmental permit no longer than 1 year since this Act takes into force.

Integration as indicated in the previous paragraph refers to unification of various, fragmented permits into a single legal product of a Decree on Environmental Permit. Referring to UU-PPLH, environmental permit is different from EIA or UKL-UPL, even though both documents are published in form of a decree. It is a part of environmental permit. Having reviewed the regulations on environment, the authors assume that Government Regulation Number 27 of 2012 concerning Environmental Permit tends to equate EIA with environmental permit, which, according to the authors, is mistaken. The title of the regulation indicates environmental permit but the content material focuses more on EIA and UKL-UPL. Article 74 of the regulation states that:

At the time this regulations takes into effect, Government Regulation Number 27 of 1999 concerning Environmental Impact Assessment (Gazette of the Republic of Indonesia of 1999 Number 59, Extra Gazette of the Republic of Indonesia Number 3838) is declared to be null and void.

Based on Article 63 and 64 of the Government Regulation on Electronic Service for Business Licensing of 2018, EIA and environmental permit is a single unit of entity, which is issued as environmental permit.

Another mistake lies on the content of the regulation. Focusing more on EIA or UKLUPL, this regulation fail to include other significant permits regarding the management of environment for business purpose. Those permits are not yet integrated into environmental permit. For example, management of B3 waste is still regulated in Government Regulation No. 101 of 2014 on Management of Toxic and Hazardous Waste.

10 Business or activity permit is a permit issued by a technical unit to allow individual operating a business or an activity (Article 1 para. 36). 
In forestry, the focus of this study is on Government Regulation Number 6 of 2007 on Forest System and the Planning of Forest Management, and Forest Utilization, ${ }^{11}$ as amended by Government Regulation Number 3 of 2008. Based on a review of the regulations, the authors found several problems that will hinder the licensing process in forestry business and activity, namely, the title of the regulation; the laws used as the legal basis (the considerations); the laws used as the legal politic; Article 19, 20, 28, 33 of the regulation; and Article 36 the Government Regulation Number 3 of 2008.12 According to the authors, with reference to $\mathrm{BPHN}$, the material content of the provisions of the aforementioned articles are not in synchronized with the Act on Forestry of 1999 and the Act Number 18 of 2013 on Prevention and Mitigation of Forest Damage.

Taking into account the concept of proper enactment of the law as indicated in Article 5 (2) of the Constitution, the provision contained in Government Regulation on Environmental Permit of 2012 Government Regulation on Forest System and the Planning of Forest Management and Forest Utilization of 2007 and of 2008 are contradicting with the Act on the Protection and Management of Environment of 2009, the Act on Forestry of 1999, and the Act Prevention and Mitigation of Forest Damage of 2013.

In relation to this, Manan mentions that the content of a government regulation should be consistent, and not separated from, the referred laws. ${ }^{13}$ Manan further explains several liabilities of delegated regulation (government regulation) as follow:

a. The content of government regulation often escaped from the oversight of the House of Representative because the President made it by himself. In some cases, the content is written beyond or deviated from the provisions of the laws;

b. Experience shows delays in the establishment of government regulations so that certain parts of the laws cannot be implemented (on the ground that there is no legal basis for operation).

It is previously mentioned that proper enactment of the law means that the President is responsible to publish and implement government regulations as mandated by the law. According to Prasetyaningsih, 14 the term proper enactment can be translated that the President may establish a government regulation if the law firmly mentions about that; that the President enforces the law by establishing a government regulation; meaning that it is firmly stated in the law that the President should establish a government regulation, however the term "properly" gives a discretion for the President to or not to establish a government regulation when the law does not firmly stated that it requires a government regulation to implement the law.

The word "may" in the statement above leads to a further analysis of this interpretation, because no one expressly agrees or disagrees with this interpretation. One thing to consider in mind is that the absence of a firm statement in the law results in the lack of the establishment of the assigned government regulation. Even worse, none of the assigned regulation is established and enforced by the President. On the

11 Lidskog, R., \& Sjödin, D. (2016). Risk governance through professional expertise. Forestry consultants' handling of uncertainties after a storm disaster. Journal of risk research, 19(10): 1275-290.

12 Pusat Analisis \& Evaluasi Hukum Nasional Badan Pembinaan Hukum Nasional Kementerian Hukum \& HAM, (2017). Laporan Akhir Kelompok Kerja Analisis Dan Evaluasi Hukum Dalam Rangka Penyelamatan dan Pengelolaan Kawasan Hutan, Jakarta, p. 161.

13 Ibid.

14 Prasetyaningsih, R. (2017). Menakar Kekuasaan Presiden Dalam Pembentukan Peraturan PerundangUndangan Menurut UUD 1945, Padjadjaran Jurnal Ilmu Hukum, 4 (2): 274. 
other hand, government regulation as the implementing regulation is required in the management of environment and forest.

Government regulation is generally established following a firm mandate of the law. Government regulation basically, an executive implementer of the provisions of the law. ${ }^{15}$ As far as the authors concern, until 2019, there five (5) government regulations on environment and forestry that are yet to be published; two (2) government regulations regarding the Act of the Protection and Management of Environment 2009 and three (3) regulations regarding the Act of Forestry of 1999.

\section{Legal Implication if the President Fails to Establish and Enforce the Government Regulation on Environment and Forestry as assigned by the Laws}

Indonesia is a state of law. ${ }^{16}$ This statement means that law is the foundation of the nation and not a mere principles written in the Constitution. The Constitution writes that:

Indonesia is based on law (rechstaat) and not on power (machtsstaat), and the principle that "the government is built upon the constitutional system (basic law), is not absolutism (unlimited power). ${ }^{17}$

Indonesia embraces the state of material law, in other words is the modern or welfare state. The objective of the nation is the establishment of a spiritually and materially fair and prosperous society based on Pancasila. This is also referred to as "a nation with an independent character." 18 The independence of the nation can be seen in the implementation and pattern of the concept of the state of law which is designed in accordance with the prevailing situation in Indonesia. This means that the benchmark is Pancasila. ${ }^{19}$ In the law state of Pancasila, the purpose of the governance is wider, that is to get involved in the life and livelihood.

The aforementioned juridical facts show that as a modern- or a welfare state, Indonesia has a strong foundation to arrange governance mechanism and delegate governance authority to manage the environment and forest justly. President holds the highest governance power (executive function) in Indonesia as indicated in the Constitution. Article 4 until Article 17 of Chapter III of the Constitution regulates the state governance authority.

In this section, the authors will discuss about the legal implications if the President does not establish and enforce government regulation as delegated in Article 5 (2) of the Constitution. The two legal implications being observed in this research are the impact on the protection and management of environment and on the President who holds the legislative power. In his opinion, Bagir Manan says that President does not only hold the executive but also the legislative power. ${ }^{20}$ It is mentioned earlier that since the commencement of the Act on the Protection and Management of

15 Asshiddiqie, J. (2017). Perihal Undang-Undang, Depok: Rajawali Pers, p. 78.

16 Manan, B. (2006). Lembaga Kepresidenan, Yogyakarta: FH UII Press, p. 25.

17 Nurlinda, I. (2009). Prinsip-prinsip Pembaharuan Agraria; Perspektif Hukum, Jakarta: Rajawali Press, p. 13.

18 Amanwinata, R. (1996). Pengaturan dan Batas Implementasi Kemerdekaan Berserikat dan Berkumpulan Dalam Pasal 28 UUD 1945, (Dissertation), Postgraduate Universitas Padjadjaran, p. 109.

19 Basah, S. (1997). Eksistensi dan Tolok Ukur Badan Peradilan Administrasi di Indonesia, Bandung: Alumni, , 3rd Eds, p. 11.

20 Bagir Manan, Op. Cit, p. 28. 
Environment in 2009 and the Act of Forestry in 1999, there are still 5 government regulations that have yet been formed.

The absence of government regulation on the management of environment and forest hinders the development program in these sectors. For example, the Act mandates that the planning for the protection and management of environment should be regulated in government regulation. The government had submitted a bill for the regulation in 2017, nevertheless, until 2019; the regulation is not yet published. Consequently, there is no legal certainty for the protection and management of environment. The same effect will also take place if the content material of the government regulation contradicts with the laws. In this case, the regulation can be cancelled before law.

The second impact is on the President who holds the power to formulate, establish, and enforce government regulation. Article 5 (2) of the Constitution emphasizes that the President should enforce the law properly, including follow through the command written in the law. This has been the obligation of the President as indicated in the requirement of being a President as well as in the oath of the President. Article 6 of the Constitution elucidates one of the requirements to become a President is implementing the duties and obligations.

(1) Any candidate for President or Vice-President shall be a citizen of Indonesia since birth, shall never have acquired another citizenship by his/her own will, shall never have committed an act of treason against the State, and shall be mentally and physically capable of implementing the duties and obligations of President or Vice-President;

(2) The requirements to become President or Vice-President shall be further regulated by law.

The inability to carry out tasks to establish government regulations as mandated in the laws can be translated into a violation against the law. In this sense, the President is perceived to be incompetent, failed to uphold the Constitution and fulfill oath and promise, therefore, longer meets the qualification to serve. It is mentioned in Article 7B of the Constitution that:

(1) Any proposal for the dismissal of the President and/or the Vice-President may be submitted by the DPR of the MPO only by first submitting a request to the Constitutional Court to investigate, bring to trial, and issue a decision on the opinion of the DPR either that the President and/or the Vice-President has violated the law through an act of treason, corruption, bribery, or other act of a grave criminal nature, or through moral turpitude, and/or that the President and/or the Vice-President no longer meets the qualifications to serve as President and/or Vice-President;

(2) The opinion of the DPR that the President and/or the Vice-President has violated the law or no longer meets the qualifications to serve as President and/or VicePresident is undertaken in the course of implementation of the supervision function on the DPR. 
With this regard, DPR, the Constitutional Court, and MPR need to assess the alleged violation thoroughly based on the proper procedures and mechanisms before coming to a conclusion.

\section{Conclusion}

The meaning of proper enforcement of the law as indicated in Article 5 (2) of the Constitution is establishment of all assigned government regulations. This means that the President establishes the government regulations, ensures that content material of the government regulations is consistent with the laws, and enforces the implementation of the law. There are two legal implications if the President is unable to implement the laws are: First, the established government regulations can be cancelled before law. Second, the President might be perceived as violating the law, the oath, and the promise. In this case, the President cannot uphold the mandate of the Constitution and fulfill the duties and obligations.

The government reviews and rearranges the existing government regulations to make sure that the material content is consistent with the laws. In addition, the Minister involved in the planning of the government regulation reviews all the prevailing laws to follow through with the establishment of mandated government regulations. Hence, it is suggested that DPR, the President, and the Minister involved in the establishment of government regulation to be careful in delegating the establishment of government regulation in the upcoming laws.

\section{References}

Amanwinata, R. (1996). Pengaturan dan Batas Implementasi Kemerdekaan Berserikat dan Berkumpulan Dalam Pasal 28 UUD 1945, (Dissertation), Postgraduate Universitas Padjadjaran.

Asshiddiqie, J. (2017). Perihal Undang-Undang, Depok: Rajawali Pers.

Basah, S. (1997). Eksistensi dan Tolok Ukur Badan Peradilan Administrasi di Indonesia, 3rd Eds. Bandung: Alumni.

Helmi and Iskandar, I. (2020). The Authority of Internal Auditor to Prevent Corruption Committed by Civil Servants and Government Official. Jambe Law Journal, 2(2): 139-62.

Lidskog, R., \& Sjödin, D. (2016). Risk governance through professional expertise. Forestry consultants' handling of uncertainties after a storm disaster. Journal of risk research, 19(10): 1275-290.

Manan, B. (2006). Lembaga Kepresidenan, Yogyakarta: FH UII Press.

Marzuki, P.M. (2005). Penelitian Hukum, Revision Edition. Jakarta: Prenadamedia Group Jakarta.

Nasution, B.J. (2008). Metode Penelitian Ilmu Hukum. Bandung: Maju Mundur.

Nurlinda, I. (2009). Prinsip-prinsip Pembaharuan Agraria; Perspektif Hukum, Jakarta: Rajawali Press. 
Prasetyaningsih, R. (2017). "Menakar Kekuasaan Presiden Dalam Pembentukan Peraturan Perundang-Undangan Menurut UUD 1945", Padjadjaran Jurnal Ilmu Hukum, 4 (2): 274.

Pusat Analisis \& Evaluasi Hukum Nasional Badan Pembinaan Hukum Nasional Kementerian Hukum \& HAM, (2017). Laporan Akhir Kelompok Kerja Analisis Dan Evaluasi Hukum Dalam Rangka Penyelamatan dan Pengelolaan Kawasan Hutan, Jakarta.

\section{Conflict of Interest Statement:}

The author(s) declares that the research was conducted in the absence of any commercial or financial relationships that could be construed as a potential conflict of interest.

Copyright (C) 2020 HALREV. All rights reserved. 